\title{
Metabolic Fate of Clonidine (I): Absorption, Distribution and Excretion in Rats, Dogs and Monkeys after Subcutaneous Administration of Clonidine
}

\author{
Tohru Yamahata, Yasuo Minaki, Hitoshi Nishikawa, Yoshio Esumi*, \\ Yoshitaka JIN*, Atsushi TAKAO*, Toshiyuki Mashiko*, Kazumi ICHIGE*, \\ Kumiko Yamashita*, Miwa OHTSUBo* and Katsuyuki Hori* \\ Central Research Laboratories, Maruho Co., Ltd., Osaka; \\ *Tokai Research Laboratories, \\ Daiichi Pure Chemicals Co., Ltd., Ibaraki
}

\begin{abstract}
Summary: After a single subcutaneous administration of ${ }^{14} \mathrm{C}$-clonidine at a dose of $1 \mathrm{mg} / \mathrm{kg}$ (principally) to rats, dogs and a monkey, the absorption, distribution and excretion of radioactivity were investigated.

1. In the male rats, the radioactivity level in plasma reached a maximum $\left(\mathrm{C}_{\max }\right)$ at $2 \mathrm{hr}$ and then declined with half-lives of $7.1 \mathrm{hr}$ up to $24 \mathrm{hr}$ and $37 \mathrm{hr}$ thereafter. The plasma levels were dose-proportional at the dosing range of 0.25 to $1 \mathrm{mg} / \mathrm{kg}$. No marked difference was observed between the males and females in the plasma level.

Most tissues showed higher radioactivity levels than that observed in the plasma, especially high levels were seen in the mandibular gland, kidney, liver and stomach. The elimination from tissues was more rapid than that in the plasma except the aorta and thyroid gland until $24 \mathrm{hr}$. High radioactivity was also found in the gastro-intestinal contents, some exocrine glands and nasal cavity as revealed by the whole body autoradiograms.

Urinary and fecal excretions within $168 \mathrm{hr}$ were 69.5 and $28.4 \%$ of the dose, respectively. Biliary excretion accounted for $33.2 \%$ of the dose within $48 \mathrm{hr}$. Entero-hepatic circulation was partly observed. In the females, urinary excretion was slightly higher than that in the males.

2. In the male dogs, the Cmax was 6 times higher and the elimination of second phase was slower than those in the male rats. Within $480 \mathrm{hr}, 87.0$ and $10.2 \%$ of the dose were excreted in urine and feces, respectively.

3. In the male monkey, the radioactivity level in plasma and urinary and fecal excretions were similar to those in dogs.
\end{abstract}

\section{Key words: Clonidine, Rat, Dog, Monkey, Absorption, Distribution, Excretion, Subcutaneous} administration

\section{Introduction}

Clonidine, $2-[(2,6-$ dichlorophenyl) imino $]$ imidazolidine, is a hypotensive drug considered to stimulate $\alpha_{2}{ }^{-}$ adrenoceptors in the central nervous system ${ }^{1)}$. Clinically, clonidine hydrochloride is orally administered twice or three times daily. In these cases, the plasma concentration of clonidine fluctuates with large amplitude and the high peak level of clonidine has been considered to be a cause of side effects ${ }^{2)}$. Transdermal administration of clonidine may depress the amplitude of plasma concentration and prolong the effective plasma level. Therefore, alleviation of the side effects and duration of the stable hypotensive effect are expected.

From these viewpoints, a new transdermal delivery system, M-5041T, containing clonidine has been de- veloping to be used for hypertension therapy. This system is a tape preparation consisted of an adhesive layer containing the drug and a backing layer. As a part of the investigation on this system, the metabolic fate of clonidine in animals was studied using [imidazolidine $-2-{ }^{-14} \mathrm{C}$ ] clonidine $\left({ }^{14} \mathrm{C}\right.$-clonidine) as a tracer.

This paper presents the absorption, distribution and excretion of radioactivity after single subcutaneous administration of ${ }^{14} \mathrm{C}$-clonidine to rats, dogs and a monkey to elucidate the metabolic fate of clonidine after the drug has penetrated through the skin.

\section{Materials and Methods}

\section{Compounds}

${ }^{14} \mathrm{C}$-Clonidine was synthesized by Chemsyn Science Laboratories and purified by Daiichi Pure Chemicals 


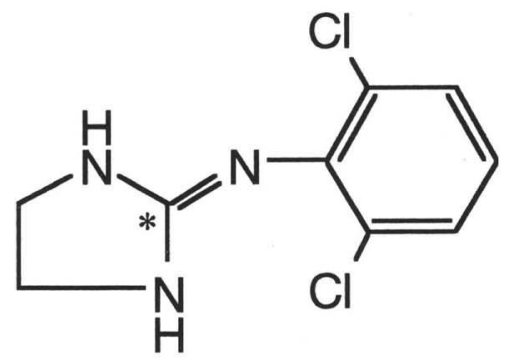

Fig. 1 Chemical structure of ${ }^{14} \mathrm{C}$-clonidine $*:{ }^{14} \mathrm{C}$-labelled position

Co., Ltd. The structure and labelled position are shown in Fig. 1. The specific activity was 8.26 to $9.08 \mathrm{MBq} /$ $\mathrm{mg}$ and the radiochemical purity was more than $96 \%$ determined by the thin-layer chromatography using silica gel $60 \mathrm{~F}_{254}$ plates (0.25 mm thickness, E. Merck) in following solvent systems; methanol, 1-butanol:acetic acid : water (5:1:4, upper layer) and ethyl acetate : ethanol : ammonia $(30: 5: 3)$. Unlabelled clonidine was purchased from Daiwa Pharmaceutical Co., Ltd.

\section{Experimental Animals}

Sprague-Dawley strain SPF rats consisting of 7 to 8 weeks old males weighing about $280 \mathrm{~g}$ and 8 weeks old females weighing about $210 \mathrm{~g}$ (SLC Japan Ltd.), male Beagle dogs of 9 to 10 months old weighing about $10 \mathrm{~kg}$ (Marshall Farms) and a male cynomolgus monkey estimated to be about 10 years old weighing about $4.4 \mathrm{~kg}$ (Philippines born, Charles River Japan, Inc.) were used.

The rats were allowed water and pellet food (MF, Oriental Yeast Co.) ad libitum and acclimatized to the conditions of $23 \pm 2^{\circ} \mathrm{C}, 55 \pm 10 \%$ relative humidity for at least a week before use. The dog got about $300 \mathrm{~g}$ of pellet food (DS-5, Oriental Yeast Co.) once daily. The monkey got about $300 \mathrm{~g}$ of pellet food (\#5048, Ralston Purina Company, U.S.A.) and fruits once daily. The dogs and monkey were acclimatized to similar conditions described above for at least a month before use.

Three animals were assigned to each experimental group but one was used for the whole body autoradiography and the studies in the monkey.

\section{Preparation of Dosing Solution and Adminis- tration of Test Article}

${ }^{14} \mathrm{C}$-Clonidine, if necessary, was mixed with unlabelled clonidine and was dissolved in saline. The solution was adjusted to $0.125,0.25$ and $0.5 \mathrm{mg} / \mathrm{ml}$ (about 1.0 to $1.85 \mathrm{MBq} / \mathrm{m} l$ ) for rats and $1 \mathrm{mg} / \mathrm{m} l$ (about 1.85 $\mathrm{MBq} / \mathrm{ml}$ ) for dogs and monkeys. These solutions were administered subcutaneously to the back of animals in a volume of $2 \mathrm{ml} / \mathrm{kg}$ for rats and $1 \mathrm{~m} l / \mathrm{kg}$ for dogs and monkeys.

\section{Measurement of Radioactivity}

Radioactivity in each sample was counted for $2 \mathrm{~min}$ with a liquid scintillation counter (LSC-903 or LSC3600 , Aloka). The counting efficiency was corrected by the channels ratio method using an external standard source.

\section{Determination of Radioactivity Concentration in Blood and Plasma \\ 1) Rats}

Blood was withdrawn periodically from the caudal vein and centrifuged $\left(1800 \times \mathrm{g}, 4^{\circ} \mathrm{C}, 15 \mathrm{~min}\right)$ after administration of ${ }^{14} \mathrm{C}$-clonidine to male and female rats. The obtained plasma ( 35 to $100 \mu l$ ) was dissolved in 2 $\mathrm{m} l$ of tissue solubilizer SOLUENE-350 (Packard). The radioactivity was counted after addition of $13 \mathrm{~m} l$ of scintillator ECONOFLUOR (Du Pont NEN Research Products).

\section{2) Dogs and monkeys}

Blood was withdrawn periodically from the cephalic vein into a heparinized vacutainer (Terumo Co.) after administration of ${ }^{14} \mathrm{C}$-clonidine to male dogs. Each 100 $\mu l$ of the blood was dissolved in $2 \mathrm{~m} l$ of tissue solubilizer SOLUENE-350 and decolored with $0.4 \mathrm{~m} l$ of benzene saturated with benzoyl peroxide. The radioactivity was counted after addition of $13 \mathrm{ml}$ of scintillator ECONOFLUOR. The remaining blood was centrifuged to obtain plasma. The radioactivity in 200 to $500 \mu l$ of plasma was counted according to the method for rats.

A monkey was treated similarly to the dogs, except that blood was withdrawn from the femoral vein.

\section{Whole Body Autoradiography}

Male rats were sacrificed by ether treatment after administration of ${ }^{14} \mathrm{C}-$ clonidine. The carcass was frozen in a dry ice/acetone mixture at $-70^{\circ} \mathrm{C}$ and occluded with $5 \%$ carboxymethyl cellulose. The sagittal sections (about $35 \mu \mathrm{m}$ thickness) were prepared with a CRYOMICROTOME (PMV 450MP, LKB) and lyophilized at $-25^{\circ} \mathrm{C}$. The sections were covered with protective films $(4 \mu \mathrm{m}$, Dia Foil) and contacted with X-ray films (MARG ${ }^{3} \mathrm{H}$ type, Konica) at $4^{\circ} \mathrm{C}$ for 21 days.

\section{Determination of Radioactivity Concentration in Tissue \\ 1) Rats}

Male rats were exsanguinated from the abdominal aorta under ether anesthesia after administration of ${ }^{14} \mathrm{C}-$ clonidine and the tissues were excised and weighed. The radioactivity in the plasma and blood was counted as described above. The radioactivity in the tissues was counted according to the method for blood. The skin at the administration site was dissolved in a mixture of designated volume of $0.5 \mathrm{M}$ sodium hydroxide and toluene by reflux for $72 \mathrm{hr}$. After an appropriate volume of water was added, the mixture was stirred to homogeneous solution. Scintillator ATOMLIGHT (Du Pont NEN Research Products) was added to an aliquot of the solution and the radioactivity was counted. 
The hematocrit value was measured with a centrifuge (Model MC-200, HITACHI) and the distribution ratio in the blood cells was calculated by following equation.

Distribution of radioactivity into blood cells (\%)

$$
=(1-\mathrm{P} / \mathrm{B} \times(100-\mathrm{Ht}) / 100) \times 100
$$

B : Radioactivity concentration in blood

$\mathrm{P}:$ Radioactivity concentration in plasma

$\mathrm{Ht}$ : Hematocrit value (\%)

\section{2) Dogs}

The dogs used for the determination of radioactivity concentrations in blood and plasma were exsanguinated from the abdominal aorta under anesthesia with ketamine hydrochloride (Sankyo Co.) : xylazine hydrochloride (Bayer Japan Ltd.) (2:1) at $480 \mathrm{hr}$ after administration and the radioactivity in the plasma, blood and tissues was counted according to the method for rats.

\section{Determination of Radioactivity Excreted in Urine and Feces \\ 1) Rats}

Male and female rats were placed in metabolic cages (KN-646B, Natsume) after administration of ${ }^{14} \mathrm{C}-$ clonidine and the excreted urine and feces were collected. The urinary sample was diluted to $100 \mathrm{~m} l$ with water and the radioactivity in $1 \mathrm{~m} l$ was counted after addition of $13 \mathrm{~m} l$ of scintillator ATOMLIGHT. The fecal sample was homogenized in 50\% methanol and diluted to 300 $\mathrm{m} l$. Each $0.5 \mathrm{~m} l$ aliquot of the homogenate was shaken overnight with $2 \mathrm{~m} l$ of tissue solubilizer SOLUENE350 . The radioactivity was counted after addition of 13 $\mathrm{m} l$ of scintillator ECONOFLUOR.

After collection of the excreta until $168 \mathrm{hr}$, the rats were sacrificed by ether treatment and were separated into the administration site (excised extensively, including the skin and skeletal muscle) and the other part. Each of them was processed in a similar manner described under the rat tissues.

\section{2) Dogs and monkeys}

The dogs used for the determination of radioactivity concentration in blood and plasma were housed in metabolic cages (designed by Daiichi Pure Chemicals, produced by Tokiwa Kagaku Kikai) and the excreted urine and feces were collected. The radioactivity was counted according to the method for rats.

After collection of the excreta until $480 \mathrm{hr}$, the metabolic cages were washed with about $8 l$ of water. The cage wash was diluted with water to $10 l$ and then the radioactivity in $1 \mathrm{~m} l$ of the diluted wash was counted after addition of $13 \mathrm{~m} l$ of scintillator ATOMLIGHT.

A monkey was treated in the same manner as the dog except using another type of metabolic cage (designed by Daiichi Pure Chemicals, produced by Showa Kagaku).

\section{Determination of Radioactivity Excreted in Bile}

Male rats were cannulated into the bile ducts with polyethylene tubes under ether anesthesia and placed in Bollman cages. After recovery from anesthesia, ${ }^{14} \mathrm{C}-$ clonidine was administered and the excreted bile, urine and feces were collected. The bile was diluted with water to $50 \mathrm{~m} l$ and the radioactivity in $1 \mathrm{~m} l$ was counted after addition of $13 \mathrm{~m} l$ of scintillator ATOMLIGHT. The radioactivity in the urine and feces was also counted.

After collection of the excreta until $48 \mathrm{hr}$, the rats were sacrificed by ether treatment and the contents in the gastro-intestinal tract were collected. The radioactivity was counted according to the method for feces. The radioactivity remaining in the administration site and carcass was also counted according to the method described above.

\section{Entero-hepatic Circulation Study}

The bile excreted for $8 \mathrm{hr}$ after administration of ${ }^{14} \mathrm{C}-$ clonidine to male rats at $1 \mathrm{mg} / \mathrm{kg}$ was collected on an ice bath as described above. A part of the bile was injected at $0.126 \mathrm{mg}$ equivalents of clonidine $/ 223 \mathrm{kBq} / 8 \mathrm{~m} l \mathrm{bile} /$ $\mathrm{kg}$ into the duodenum of different male rats cannulated into the bile duct. Subsequently, the rats were processed in a similar manner described above.

\section{Expression of Results}

The radioactivity concentration was converted to the equivalent value of clonidine. Results were expressed as the mean values and standard deviations (S.D.). Pharmacokinetic parameters were calculated from the mean values of three animals except the study in the monkey. Half-life was expressed as the apparent value that was calculated by the least square regression. Area under radioactivity concentration in plasma vs. time curve (AUC) was calculated by following equations.

$$
\begin{aligned}
\mathrm{AUC}= & \mathrm{AUC}_{0-\mathrm{t}}+\mathrm{AUC}_{\mathrm{t}} / \mathrm{k}_{\mathrm{el}} \\
\mathrm{AUC}_{0-\mathrm{t}}: & \text { The } \mathrm{AUC} \text { throughout detectable time } \\
& \text { points that was calculated by the } \\
& \text { trapezoidal method }
\end{aligned}
$$

$\mathrm{C}_{\mathrm{t}}$ : Concentration of radioactivity in plasma at the final time of detectable points

$k_{\mathrm{el}}$ : Elimination rate constant at the final phase

\section{Results}

\section{Radioactivity Concentration in Blood and Plas- ma \\ 1) Rats}

In the male rats received ${ }^{14} \mathrm{C}$-clonidine at a dose of $0.25,0.5$ and $1 \mathrm{mg} / \mathrm{kg}$ subcutaneously, the radioactivity concentrations in plasma reached respective maxima $\left(\mathrm{C}_{\max }\right)$ at $2 \mathrm{hr}$ in all dose groups. The half-lives were 6.4 to $7.2 \mathrm{hr}$ between 4 and $24 \mathrm{hr}$ after administration and 33 to $37 \mathrm{hr}$ between $48 \mathrm{hr}$ and the last time point. The $\mathrm{C}_{\max }$ and AUC were almost dose-proportional (Fig. 2 and Table I).

In the female rats received a dose of $1 \mathrm{mg} / \mathrm{kg}$, the profile of radioactivity concentration in plasma was 




Fig. 2 Radioactivity concentrations in plasma after subcutaneous administration of ${ }^{14} \mathrm{C}$-clonidine to rats Data are expressed as the mean values \pm S.D. of three animals.

Table I Pharmacokinetic parameters of radioactivity in plasma after subcutaneous administration of ${ }^{14} \mathrm{C}$-clonidine to male and female rats

\begin{tabular}{|c|c|c|c|c|c|c|c|}
\hline \multirow{2}{*}{ Sex } & \multirow{2}{*}{$\begin{array}{c}\text { Dose } \\
(\mathrm{mg} / \mathrm{kg})\end{array}$} & \multicolumn{6}{|c|}{ Pharmacokinetic parameters } \\
\hline & & $\begin{array}{l}T_{\max } \\
(\mathrm{hr})\end{array}$ & $\underset{\text { (ng equiv. } / \mathrm{m} l \text { ) }}{\mathrm{C}_{\max }}$ & $\begin{array}{l}\mathrm{t}_{1 / 2} \\
(\mathrm{hr})\end{array}$ & $\begin{array}{c}\text { AUC } \\
(\mu \mathrm{g} \text { equiv. } \cdot \mathrm{hr} / \mathrm{m} l)\end{array}$ & $\underset{(\mathrm{hr})}{\mathrm{MRT}}$ & $\begin{array}{l}\text { VRT } \\
\left(\mathrm{hr}^{2}\right)\end{array}$ \\
\hline \multirow{3}{*}{ Male } & 0.25 & 2 & 41.4 & $\begin{array}{r}7.2(4-24 \mathrm{hr}) \\
33 \quad(48-96 \mathrm{hr})\end{array}$ & 0.554 & 18.1 & 503 \\
\hline & 0.5 & 2 & 90.4 & $\begin{array}{r}6.4(4-24 \mathrm{hr}) \\
35 \quad(48-120 \mathrm{hr})\end{array}$ & 1.22 & 17.4 & 528 \\
\hline & 1 & 2 & 168.9 & $\begin{array}{r}7.1(4-24 \mathrm{hr}) \\
37 \quad(48-120 \mathrm{hr})\end{array}$ & 2.52 & 17.6 & 499 \\
\hline Female & 1 & 2 & 171.7 & $\begin{array}{r}8.7(4-24 \mathrm{hr}) \\
32 \quad(48-120 \mathrm{hr})\end{array}$ & 2.81 & 18.7 & 499 \\
\hline
\end{tabular}

Parameters were calculated from the mean values of plasma concentrations $(n=3)$.

almost similar to that in the males (Fig. 2 and Table I).

2) Dogs

In the male dogs received a dose of $1 \mathrm{mg} / \mathrm{kg}$, the radioactivity concentration in plasma reached a $\mathrm{C}_{\max }$ of $980.7 \mathrm{ng} / \mathrm{ml}$ at $4 \mathrm{hr}$ after administration and thereafter declined with half-lives of $9.0 \mathrm{hr}$ (between 6 and $24 \mathrm{hr}$ ) and $190 \mathrm{hr}$ (between 48 and $480 \mathrm{hr}$ ). The AUC was $40.6 \mu \mathrm{g} \cdot \mathrm{hr} / \mathrm{ml}$. The radioactivity concentration in blood reached a $\mathrm{C}_{\max }$ of $678.7 \mathrm{ng} / \mathrm{ml}$ at $4 \mathrm{hr}$ and declined with similar half-lives to those in the plasma. The concentration in the blood was higher than that in plasma up to 1 $\mathrm{hr}$ and profiled low after $2 \mathrm{hr}$. Therefore, the transfer of radioactivity to the blood cells was suggested to be low (Fig. 3).

\section{3) Monkeys}

In the male monkey received a dose of $1 \mathrm{mg} / \mathrm{kg}$, the radioactivity concentration in plasma reached a $\mathrm{C}_{\max }$ of $703.0 \mathrm{ng} / \mathrm{m} l$ at $8 \mathrm{hr}$ and thereafter declined with halflives of $12 \mathrm{hr}$ (between 12 and $48 \mathrm{hr}$ ) and $160 \mathrm{hr}$ (be- tween 120 and $480 \mathrm{hr}$ ). The AUC was $32.2 \mu \mathrm{g} \cdot \mathrm{hr} / \mathrm{ml}$. The radioactivity concentration in blood reached a $\mathrm{C}_{\max }$ of $609.1 \mathrm{ng} / \mathrm{ml}$ at $4 \mathrm{hr}$ and declined with similar halflives to those in the plasma. The concentration in the blood was higher than that in plasma up to $2 \mathrm{hr}$ and profiled low after $4 \mathrm{hr}$. Similarly to the dog, the transfer of radioactivity to the blood cells was suggested to be low (Fig. 4).

\section{Whole Body Autoradiograms}

Fig. 5 shows the whole body autoradiograms after subcutaneous administration of ${ }^{14} \mathrm{C}$-clonidine to male rats at a dose of $1 \mathrm{mg} / \mathrm{kg}$.

At $2 \mathrm{hr}$ after administration, high level of radioactivity was found in the administration site, urine in bladder, preputial gland, gastric contents, intestinal contents, exorbital lacrimal gland, intraorbital lacrimal gland, nasal cavity and bulbourethral gland, followed by the levels in the mandibular gland, kidney and liver. The radioactivi- 


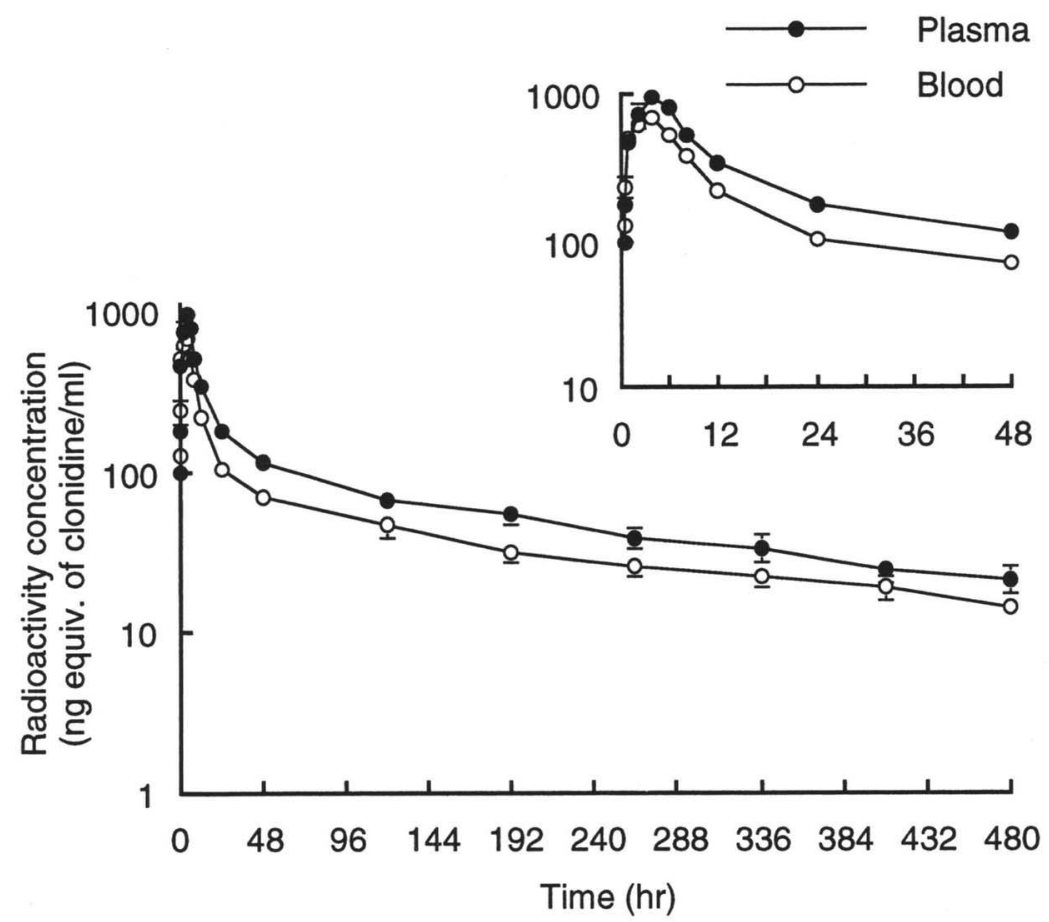

Fig. 3 Radioactivity concentrations in blood and plasma after subcutaneous administration of ${ }^{14} \mathrm{C}$-clonidine to male dogs (dose: $1 \mathrm{mg} / \mathrm{kg}$ )

Data are expressed as the mean values \pm S.D. of three animals.

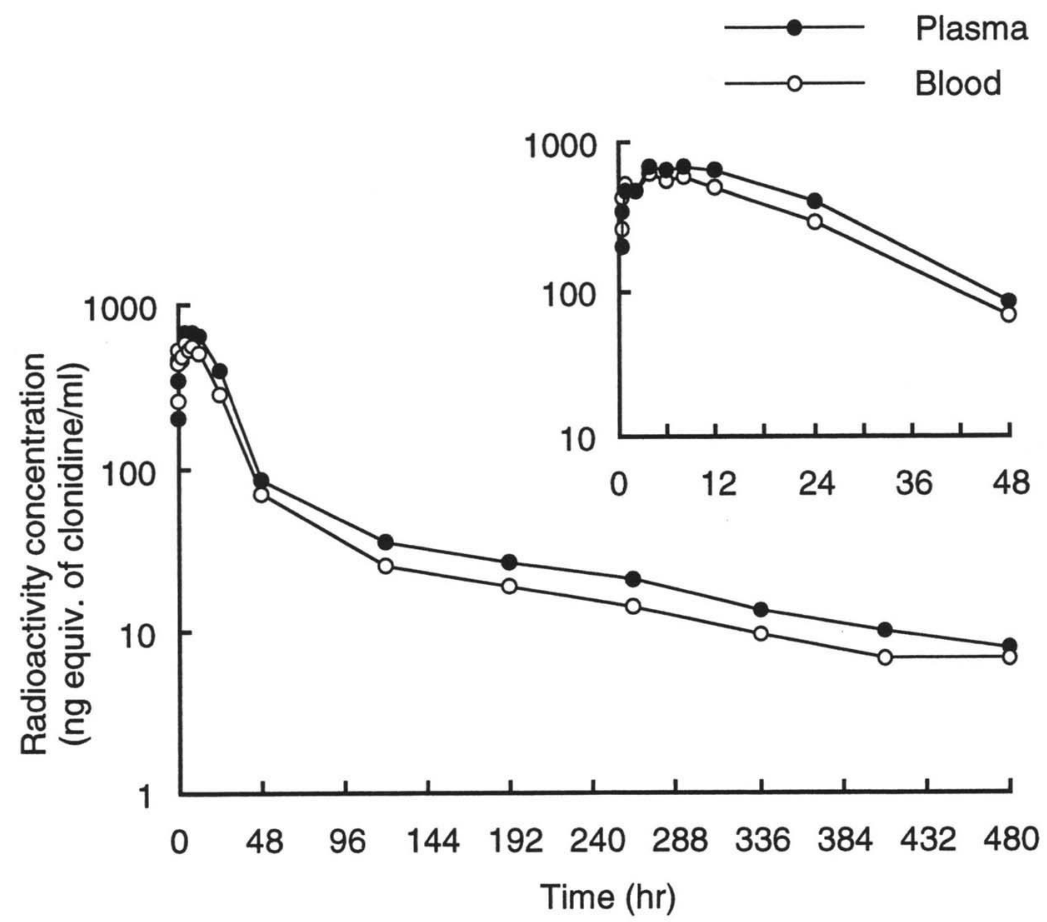

Fig. 4 Radioactivity concentrations in blood and plasma after subcutaneous administration of ${ }^{14} \mathrm{C}$-clonidine to a male monkey (dose: $1 \mathrm{mg} / \mathrm{kg}$ )

ties in the spleen, hypophysis, pancreas, adrenal gland, bone marrow, thyroid gland lung and brain were higher than that in blood. The eyeball and fat showed lower radioactivity than that in blood. At 8 and $24 \mathrm{hr}$, the overall radioactivity in the body decreased. The distribution pattern was similar to that at $2 \mathrm{hr}$. 

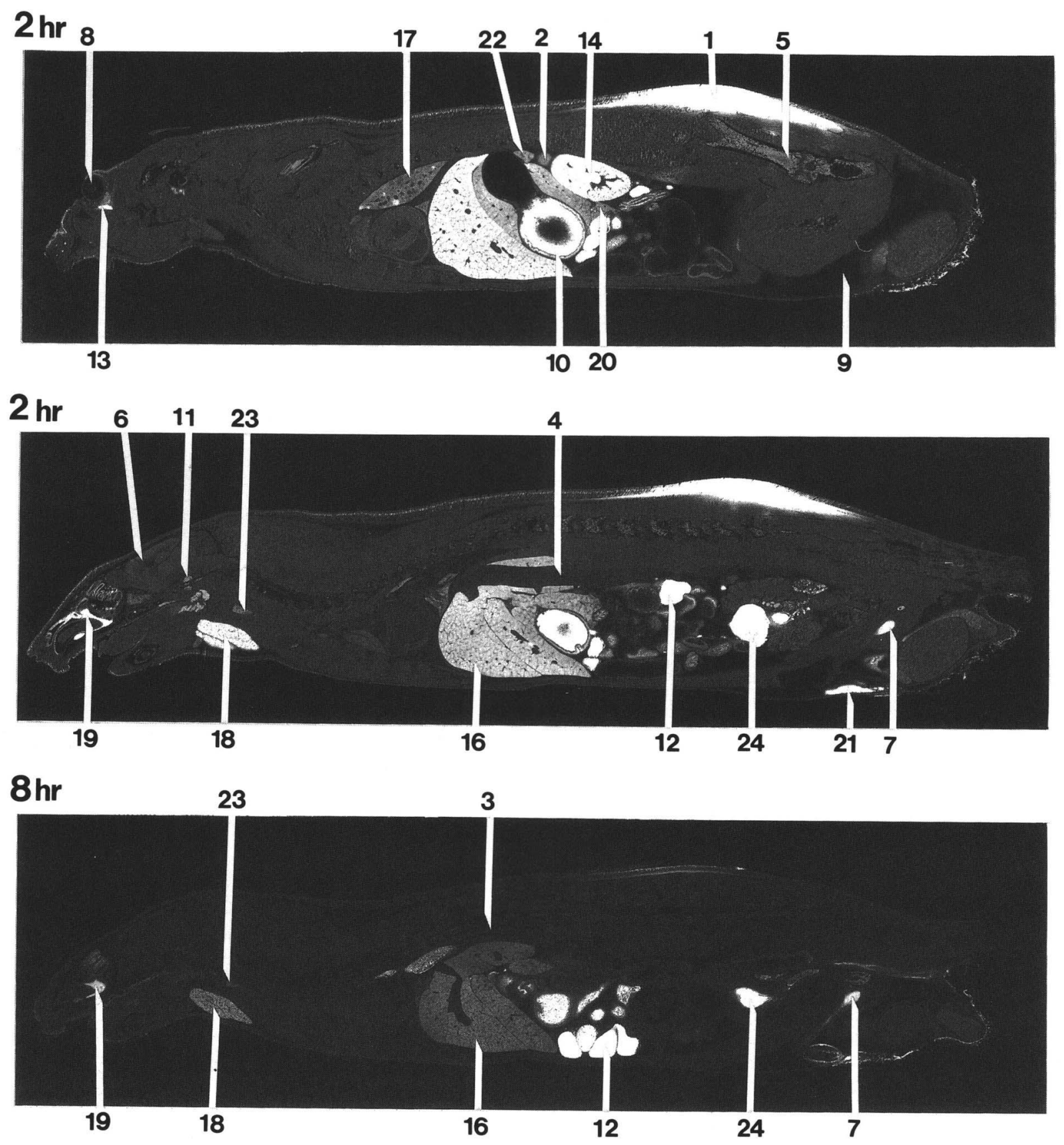

Fig. 5 Typical whole body autoradiograms after subcutaneous administration of ${ }^{14} \mathrm{C}$-clonidine to male rats (dose: $1 \mathrm{mg} /$ $\mathrm{kg})$

1. Administration site 2. Adrenal gland 3. Aorta 4. Blood 5. Bone marrow 6. Brain

7. Bulbourethral gland 8. Eyeball 9. Fat 10. Gastric contens 11. Hypophysis 12. Intestinal contents



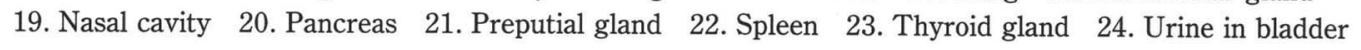

At $120 \mathrm{hr}$, although the radioactivity was eliminated from almost all of the tissues, the levels were relatively high in the administration site and preputial gland, followed by trace in the thyroid gland, aorta, intestinal contents, liver and kidney.

\section{Radioactivity Concentration in Tissue \\ 1) Rats}

The radioactivity concentrations in the tissues after subcutaneous administration of ${ }^{14} \mathrm{C}$-clonidine to male rats at a dose of $1 \mathrm{mg} / \mathrm{kg}$ are shown in Table II. All of the tissues examined showed maximum concentrations 
$24 \mathrm{hr}$

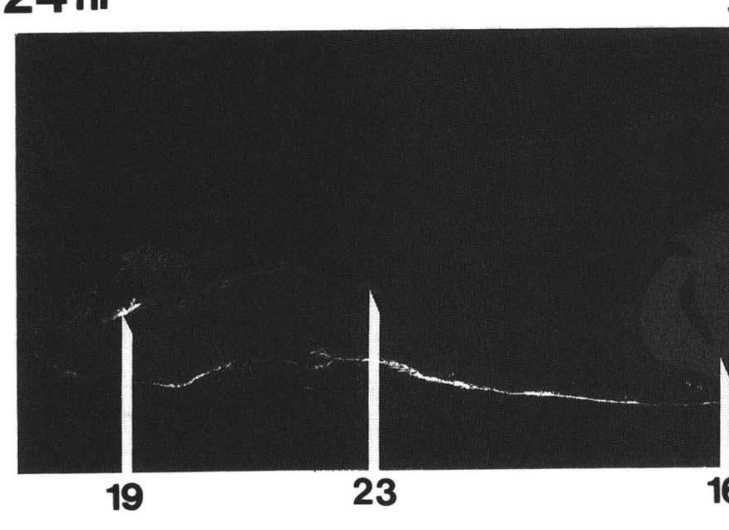

3

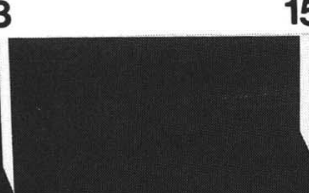

151



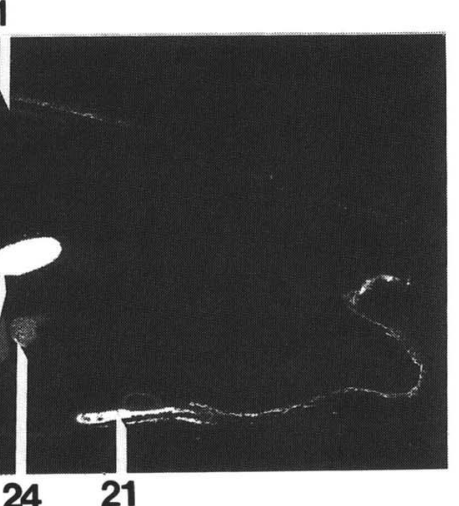

\section{$120 \mathrm{hr}$} 3 1

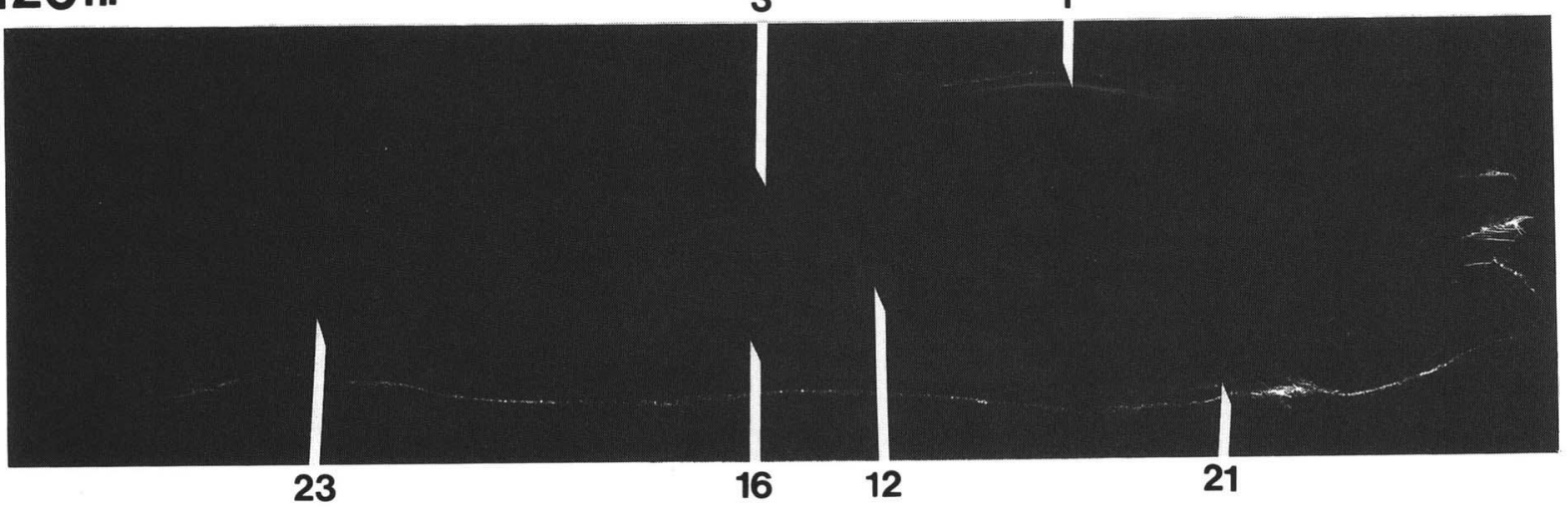

Fig. 5 Continued

at $30 \mathrm{~min}$ or $2 \mathrm{hr}$ after administration.

At $2 \mathrm{hr}$, the radioactivity concentrations in the tissues except the eyeball and fat were found higher than that in plasma $(205.6 \mathrm{ng} / \mathrm{m} l)$. High concentration was observed in the mandibular gland, kidney, liver and stomach that contained 11 to 16 times higher than that in plasma.

The radioactivities in the tissues except the thyroid gland and aorta were eliminated more rapidly than that in plasma and decreased to less than $12 \%$ of the respective maxima at $24 \mathrm{hr}$ after administration. Afterwards, they were eliminated in parallel with plasma and decreased to less than $2 \%$ or undetectable level at 120 hr. However, concentrations in the aorta and thyroid gland were 11 and $6 \%$ of their respective maxima at $120 \mathrm{hr}$. The residual radioactivities in the administration site at $0.5,2$ and $8 \mathrm{hr}$ after dosing were 27.2, 10.1 and $0.8 \%$ of the dose respectively and thereafter, decreased about $0.2 \%$.

The distribution ratio of radioactivity in the blood cells increased gradually with the elapse of time (Table III).

\section{2) Dogs}

The radioactivity concentrations in the tissues at 480 $\mathrm{hr}$ after subcutaneous administration of ${ }^{14} \mathrm{C}$-clonidine to male dogs at a dose of $1 \mathrm{mg} / \mathrm{kg}$ are shown in Table IV. Compared with the concentration in plasma $(22.0 \mathrm{ng} /$ $\mathrm{ml}$ ), the highest level was found in the aorta, moderate higher in the thyroid gland, liver and lung, slightly higher in the kidney, similar in the adrenal gland and less in the others.

\section{Excretion of Radioactivity in Urine and Feces 1) Rats}

In the male and female rats received ${ }^{14} \mathrm{C}$-clonidine at a dose of $1 \mathrm{mg} / \mathrm{kg}$ subcutaneously, the excretions of radioactivity in the urine and feces were approximately completed by 24 and $48 \mathrm{hr}$ after administration, respectively. In the male rats, 69.5 and $28.4 \%$ of the dose were excreted in the urine and feces, respectively, within 168 $\mathrm{hr}$. In the female rats, the ratio of excretion in the urine was slightly higher than that in the male rats. The values of total excretion were $97.8 \%$ of the dose in the males and $95.2 \%$ in the females. At this time, less than 0.2 and about $1 \%$ of the dose remained in the administration sites and carcasses, respectively, in both sex (Table V).

\section{2) Dogs}

In the male dogs received a dose of $1 \mathrm{mg} / \mathrm{kg}, 80.0 \%$ of the dose was excreted in the urine and feces within 24 $\mathrm{hr}$, but thereafter the radioactivity was excreted slowly. 
Table II Radioactivity concentrations in tissues after subcutaneous administration of ${ }^{14} \mathrm{C}$-clonidine to male rats (dose: $1 \mathrm{mg} /$ $\mathrm{kg}$ )

\begin{tabular}{|c|c|c|c|c|c|}
\hline \multirow{2}{*}{ Tissue } & \multicolumn{5}{|c|}{ Radioactivity concentration (ng equiv. of clonidine/g or $\mathrm{m} l$ ) } \\
\hline & $30 \mathrm{~min}$ & $2 \mathrm{hr}$ & $8 \mathrm{hr}$ & $24 \mathrm{hr}$ & $120 \mathrm{hr}$ \\
\hline Plasma & $182.5 \pm 16.0$ & $205.6 \pm 17.4$ & $110.2 \pm 13.8$ & $27.2 \pm 5.8$ & $1.5 \pm 0.2$ \\
\hline Blood & $208.2 \pm 28.2$ & $209.7 \pm 11.2$ & $100.3 \pm 8.2$ & $24.7 \pm 5.3$ & $2.6 \pm 0.7$ \\
\hline Cerebrum & $582.6 \pm 31.0$ & $628.3 \pm 40.0$ & $110.7 \pm 6.9$ & $14.5 \pm 3.2$ & $0.7 \pm 0.2$ \\
\hline Cerebellum & $455.4 \pm 17.9$ & $468.0 \pm 34.2$ & $92.5 \pm 6.0$ & $13.3 \pm 2.9$ & $0.7 \pm 0.1$ \\
\hline Hypophysis & $1178.2 \pm 50.9$ & $1278.8 \pm 304.2$ & $178.0 \pm 4.2$ & $37.7 \pm 27.0$ & N.D. \\
\hline Eyeball & $151.0 \pm 2.4$ & $193.5 \pm 16.0$ & $69.7 \pm 7.3$ & $13.6 \pm 1.6$ & $0.8 \pm 0.1$ \\
\hline Harderian gland & $767.8 \pm 142.7$ & $996.9 \pm 29.2$ & $203.5 \pm 88.0$ & $29.3 \pm 3.5$ & $1.3 \pm 0.1$ \\
\hline Thyroid gland & $611.5 \pm 19.8$ & $751.1 \pm 143.8$ & $250.9 \pm 75.5$ & $196.8 \pm 7.2$ & $43.4 \pm 19.5$ \\
\hline Mandibular gland & $1812.9 \pm 360.3$ & $3360.3 \pm 351.4$ & $872.9 \pm 195.7$ & $49.4 \pm 3.9$ & $1.4 \pm 0.2$ \\
\hline Lymphnode & $553.9 \pm 45.7$ & $717.3 \pm 36.7$ & $145.6 \pm 17.0$ & $25.6 \pm 8.3$ & N.D. \\
\hline Thymus & $457.7 \pm 18.4$ & $580.5 \pm 25.7$ & $109.4 \pm 10.4$ & $16.3 \pm 4.5$ & N.D. \\
\hline Heart & $354.9 \pm 11.8$ & $380.9 \pm 31.3$ & $117.5 \pm 11.9$ & $25.1 \pm 7.4$ & $2.7 \pm 0.2$ \\
\hline Lung & $560.9 \pm 54.4$ & $875.7 \pm 33.1$ & $212.2 \pm 64.5$ & $48.6 \pm 7.8$ & $6.6 \pm 0.3$ \\
\hline Liver & $1913.5 \pm 176.8$ & $2433.2 \pm 118.3$ & $775.3 \pm 135.5$ & $246.6 \pm 46.2$ & $36.8 \pm 1.2$ \\
\hline Kidney & $3095.6 \pm 373.3$ & $3127.2 \pm 544.4$ & $1147.1 \pm 240.7$ & $127.0 \pm 45.4$ & $15.1 \pm 2.2$ \\
\hline Adrenal gland & $770.2 \pm 122.1$ & $1069.1 \pm 60.2$ & $304.0 \pm 44.0$ & $74.4 \pm 19.3$ & $16.6 \pm 3.1$ \\
\hline Spleen & $1054.2 \pm 47.8$ & $1097.4 \pm 42.0$ & $234.7 \pm 12.3$ & $33.9 \pm 11.1$ & $2.5 \pm 0.4$ \\
\hline Pancreas & $929.2 \pm 78.0$ & $994.5 \pm 178.7$ & $225.8 \pm 22.8$ & $32.7 \pm 12.3$ & $1.4 \pm 0.1$ \\
\hline Fat & $80.9 \pm 6.8$ & $97.7 \pm 7.0$ & $26.3 \pm 5.8$ & $4.7 \pm 2.1$ & N.D. \\
\hline Brown fat & $204.7 \pm 17.9$ & $297.3 \pm 24.1$ & $87.9 \pm 14.1$ & $13.8 \pm 3.3$ & $2.1 \pm 0.6$ \\
\hline Skeletal muscle & $312.3 \pm 53.3$ & $418.5 \pm 23.8$ & $114.8 \pm 15.2$ & $18.3 \pm 5.5$ & N.D. \\
\hline Skin & $310.0 \pm 15.9$ & $442.3 \pm 75.5$ & $166.9 \pm 30.2$ & $35.8 \pm 4.7$ & $5.7 \pm 1.8$ \\
\hline Bone marrow & $957.8 \pm 91.1$ & $970.8 \pm 48.4$ & $180.8 \pm 14.0$ & $33.2 \pm 8.0$ & N.D. \\
\hline Aorta & $242.7 \pm 40.2$ & $348.9 \pm 83.9$ & $109.1 \pm 11.8$ & $71.2 \pm 32.0$ & $39.0 \pm 2.2$ \\
\hline Testis & $302.0 \pm 14.0$ & $543.5 \pm 13.9$ & $185.4 \pm 6.7$ & $18.0 \pm 3.4$ & N.D. \\
\hline Epididymis & $350.5 \pm 14.7$ & $583.5 \pm 43.6$ & $201.5 \pm 12.3$ & $20.7 \pm 4.9$ & $1.1 \pm 0.2$ \\
\hline Prostate gland & $476.6 \pm 128.1$ & $450.8 \pm 117.8$ & $107.1 \pm 7.1$ & $21.3 \pm 7.1$ & N.D. \\
\hline Stomach & $1700.9 \pm 1330.7$ & $2243.9 \pm 628.1$ & $315.5 \pm 87.7$ & $36.2 \pm 9.4$ & $2.0 \pm 0.6$ \\
\hline Small intestine & $507.4 \pm 104.4$ & $1636.9 \pm 1530.8$ & $272.0 \pm 23.4$ & $52.9 \pm 25.5$ & N.D. \\
\hline Large intestine & $476.5 \pm 70.0$ & $571.9 \pm 115.2$ & $131.9 \pm 14.7$ & $57.7 \pm 7.7$ & $1.8 \pm 0.8$ \\
\hline
\end{tabular}

Data are expressed as the mean values \pm S.D. of three animals.

N.D. : Not detected.

Table III Distribution ratio of radioactivity in blood cells after subcutaneous administration of ${ }^{14} \mathrm{C}$-clonidine to male rats (dose: $1 \mathrm{mg} / \mathrm{kg}$ )

\begin{tabular}{ccc}
\hline Time & $\begin{array}{c}\text { Ratio of radioactivity } \\
\text { in blood cells (\%) }\end{array}$ & Hematocrit (\%) \\
\hline $30 \mathrm{~min}$ & $52.9 \pm 9.0$ & $47 \pm 3$ \\
$2 \mathrm{hr}$ & $53.3 \pm 0.9$ & $52 \pm 1$ \\
8 & $46.5 \pm 6.5$ & $51 \pm 3$ \\
24 & $34.4 \pm 3.7$ & $40 \pm 2$ \\
120 & $62.1 \pm 9.3$ & $37 \pm 2$ \\
\hline
\end{tabular}

Data are expressed as the mean values \pm S.D. of three animals.
Table IV Radioactivity concentrations in tissues at 480 $\mathrm{hr}$ after subcutaneous administration of ${ }^{14} \mathrm{C}$ clonidine to male dogs (dose: $1 \mathrm{mg} / \mathrm{kg}$ )

\begin{tabular}{lc}
\hline \multicolumn{1}{c}{ Tissue } & $\begin{array}{c}\text { Radioactivity concentration } \\
\text { (ng equiv. of clonidine/g or } \mathrm{m} l \text { ) }\end{array}$ \\
\hline Plasma & $22.0 \pm 3.6$ \\
Blood & $13.9 \pm 3.1$ \\
Liver & $87.8 \pm 11.8$ \\
Kidney & $39.1 \pm 11.6$ \\
Adrenal gland & $19.3 \pm 3.6$ \\
Spleen & $15.4 \pm 3.2$ \\
Mandibular gland & $10.0 \pm 2.7$ \\
Thyroid gland & $88.5 \pm 25.9$ \\
Lung & $66.6 \pm 18.4$ \\
Aorta & $199.0 \pm 41.7$ \\
\hline
\end{tabular}

Data are expressed as the mean values \pm S.D. of three animals. 
Table V Cumulative excretions of radioactivity in urine and feces after subcutaneous administration of ${ }^{14} \mathrm{C}$-clonidine to rats (dose: $1 \mathrm{mg} / \mathrm{kg}$ )

\begin{tabular}{|c|c|c|c|c|c|c|}
\hline \multirow{3}{*}{ Time $(h r)$} & \multicolumn{6}{|c|}{ Excretion of radioactivity ( $\%$ of dose) } \\
\hline & \multicolumn{3}{|c|}{ Male } & \multicolumn{3}{|c|}{ Female } \\
\hline & Urine & Feces & Total & Urine & Feces & Total \\
\hline $0-\quad 4$ & $31.5 \pm 1.2$ & - & - & $40.6 \pm 3.0$ & - & - \\
\hline 8 & $45.9 \pm 4.9$ & - & - & $57.1 \pm 3.8$ & - & - \\
\hline 24 & $66.2 \pm 5.0$ & $23.9 \pm 1.9$ & $90.1 \pm 3.2$ & $76.3 \pm 3.9$ & $9.9 \pm 1.9$ & $86.2 \pm 2.7$ \\
\hline 48 & $68.5 \pm 4.0$ & $27.3 \pm 3.8$ & $95.8 \pm 1.6$ & $78.8 \pm 3.4$ & $14.6 \pm 3.1$ & $93.3 \pm 0.4$ \\
\hline 72 & $68.9 \pm 3.8$ & $27.8 \pm 4.0$ & $96.7 \pm 1.6$ & $79.3 \pm 3.5$ & $15.1 \pm 3.1$ & $94.4 \pm 0.5$ \\
\hline 96 & $69.1 \pm 3.8$ & $28.0 \pm 4.1$ & $97.2 \pm 1.5$ & $79.5 \pm 3.5$ & $15.3 \pm 3.1$ & $94.8 \pm 0.5$ \\
\hline 120 & $69.3 \pm 3.8$ & $28.2 \pm 4.2$ & $97.5 \pm 1.6$ & $79.7 \pm 3.5$ & $15.3 \pm 3.1$ & $94.9 \pm 0.5$ \\
\hline 144 & $69.4 \pm 3.8$ & $28.3 \pm 4.2$ & $97.6 \pm 1.6$ & $79.8 \pm 3.6$ & $15.3 \pm 3.1$ & $95.1 \pm 0.5$ \\
\hline 168 & $69.5 \pm 3.8$ & $28.4 \pm 4.3$ & $97.8 \pm 1.7$ & $79.9 \pm 3.6$ & $15.3 \pm 3.1$ & $95.2 \pm 0.5$ \\
\hline \multicolumn{2}{|c|}{ Administration site $(168 \mathrm{hr})$} & & $0.2 \pm 0.1$ & & & $0.1 \pm 0.1$ \\
\hline \multicolumn{2}{|c|}{ Carcass $(168 \mathrm{hr})$} & & $1.1 \pm 0.6$ & & & $0.8 \pm 0.1$ \\
\hline
\end{tabular}

Data are expressed as the mean values \pm S.D. of three animals.

$-:$ Not determined.

Table VI Cumulative excretions of radioactivity in urine and feces after subcutaneous administration of ${ }^{14} \mathrm{C}$-clonidine to male dogs (dose: $1 \mathrm{mg} / \mathrm{kg}$ )

\begin{tabular}{cccc}
\hline & & Excretion of radioactivity (\% of dose) & Total \\
\cline { 2 - 4 } Time $(\mathrm{hr})$ & Urine & Feces & - \\
\hline-4 & $23.6 \pm 8.0$ & - & - \\
8 & $42.2 \pm 9.3$ & $4.0 \pm 1.3$ & $88.3 \pm 2.2$ \\
24 & $76.0 \pm 2.1$ & $7.4 \pm 0.8$ & $91.7 \pm 2.5$ \\
48 & $80.9 \pm 2.4$ & $8.7 \pm 0.7$ & $93.3 \pm 2.4$ \\
72 & $83.0 \pm 2.3$ & $9.1 \pm 0.7$ & $94.1 \pm 2.3$ \\
96 & $84.2 \pm 2.2$ & $9.4 \pm 0.8$ & $94.7 \pm 2.2$ \\
120 & $84.7 \pm 2.1$ & $9.5 \pm 0.8$ & $95.3 \pm 2.1$ \\
144 & $85.2 \pm 2.0$ & $9.6 \pm 0.8$ & $95.7 \pm 2.1$ \\
168 & $85.6 \pm 1.9$ & $9.7 \pm 0.8$ & $96.2 \pm 2.2$ \\
192 & $85.9 \pm 1.9$ & $9.9 \pm 0.8$ & $96.7 \pm 2.1$ \\
336 & $86.3 \pm 1.9$ & $10.0 \pm 0.8$ & $97.0 \pm 2.1$ \\
408 & $86.6 \pm 1.9$ & $10.1 \pm 0.8$ & $97.2 \pm 2.1$ \\
\hline
\end{tabular}

Data are expressed as the mean values \pm S.D. of three animals.

$-:$ Not determined.

Within $480 \mathrm{hr}, 87.0$ and $10.2 \%$ of the dose were excreted in the urine and feces, respectively, and the value of total excretion was $97.2 \%$ (Table VI).

\section{3) Monkeys}

In the male monkey received a dose of $1 \mathrm{mg} / \mathrm{kg}$, $73.1 \%$ of the dose was excreted in the urine and feces within $24 \mathrm{hr}$, but thereafter the radioactivity was excreted slowly. Within $480 \mathrm{hr}, 86.1 \%$ and $8.6 \%$ of the dose were excreted in the urine and feces, respectively, and the value of total excretion was 94.7\% (Table VII).

\section{Excretion of Radioactivity in Bile}

After subcutaneous administration of ${ }^{14} \mathrm{C}$-clonidine to bile-duct cannulated male rats at a dose of $1 \mathrm{mg} / \mathrm{kg}$, $33.2,61.9$ and $0.2 \%$ of the dose were excreted in the bile, urine and feces, respectively, within $48 \mathrm{hr}$. No radioactivity was detected in the gastro-intestinal contents at $48 \mathrm{hr}$ after administration. At this time, 0.2 and 
$1.1 \%$ of the dose remained in the administration site and carcass, respectively (Table VIII).

\section{Entero-hepatic Circulation}

Bile was collected from the male rats that were given subcutaneously ${ }^{14} \mathrm{C}$-clonidine at a dose of $1 \mathrm{mg} / \mathrm{kg}$ and was injected into the duodenum of different bile-duct cannulated male rats. Within $48 \mathrm{hr}$ after injection, 11.0, 51.0 and $29.2 \%$ of the dose were excreted in the bile, urine and feces, respectively. In the gastro-intestinal

Table VII Cumulative excretions of radioactivity in urine and feces after subcutaneous administration of ${ }^{14} \mathrm{C}$-clonidine to a male monkey (dose: $1 \mathrm{mg} / \mathrm{kg}$ )

\begin{tabular}{rccc}
\hline \multirow{2}{*}{ Time $(\mathrm{hr})$} & \multicolumn{3}{c}{$\begin{array}{c}\text { Excretion of radioactivity } \\
\text { (\% of dose) }\end{array}$} \\
\cline { 2 - 4 } & Urine & Feces & Total \\
\hline $0-\quad 4$ & 24.9 & - & - \\
8 & 42.0 & - & - \\
24 & 72.9 & 0.2 & 73.1 \\
48 & 80.2 & 3.8 & 84.0 \\
72 & 82.8 & 6.7 & 89.5 \\
96 & 83.7 & 7.9 & 91.6 \\
120 & 84.4 & 8.2 & 92.6 \\
144 & 84.9 & 8.3 & 93.2 \\
168 & 85.1 & 8.3 & 93.4 \\
192 & 85.3 & 8.3 & 93.6 \\
264 & 85.6 & 8.4 & 94.0 \\
336 & 85.8 & 8.5 & 94.3 \\
408 & 86.0 & 8.6 & 94.6 \\
480 & 86.1 & 8.6 & 94.7 \\
\hline
\end{tabular}

Cage washing $(480 \mathrm{hr})$ 0.7

- : Not determined. contents, $4.0 \%$ of the injected dose was located (Table IX).

\section{Discussion}

A new transdermal delivery system for clonidine, M5041T, has been developing to be used for hypertension therapy. The metabolic fate of clonidine after dermal application of $\mathrm{M}-5041 \mathrm{~T}$ was studied using ${ }^{14} \mathrm{C}$-labelled clonidine. In this paper, to elucidate the metabolic fate of clonidine after penetrating through the skin, the radioactivity was traced after subcutaneous administration of ${ }^{14} \mathrm{C}$-clonidine to rats, dogs and a monkey.

Throughout this series of study, [imidazolidine-2$\left.{ }^{14} \mathrm{C}\right]$ clonidine ${ }^{3)}$ was used as a tracer. A preliminary experiment indicated that this labelled position was stable in rats because no radioactivity was detected in the expired air within $120 \mathrm{hr}$ after subcutaneous administration of this labelled compound at a dose of $1 \mathrm{mg} / \mathrm{kg}$ to a male rat.

Synthesized ${ }^{14} \mathrm{C}$-clonidine had specific activities of 8.26 to $9.08 \mathrm{MBq} / \mathrm{mg}$, which were nearly carrier-free $(10 \mathrm{MBq} / \mathrm{mg})$. When this ${ }^{14} \mathrm{C}$-clonidine was administered intravenously to a male rat at a dose of 0.1 $\mathrm{mg} / \mathrm{kg}$, the radioactivity in plasma could be traced only up to $24 \mathrm{hr}$ after administration. Therefore, a dose of 1 $\mathrm{mg} / \mathrm{kg}$ was principally administered in this study.

After subcutaneous administration of $0.25,0.5$ or 1 $\mathrm{mg} / \mathrm{kg}$ dose to male rats, the radioactivity concentrations in plasma vs. time curve were parallel to each other with dose-proportional $\mathrm{C}_{\max }$ and AUC and similar halflives, therefore, dose linearity was indicated on the metabolic fate of clonidine in the range of these dose levels. After subcutaneous administration of $1 \mathrm{mg} / \mathrm{kg}$ dose to male rats, the radioactivity concentrations in each tissue reached respective maxima between $30 \mathrm{~min}$ and $2 \mathrm{hr}$. The concentrations in the tissues except the eyeball and fat were higher than that in plasma. Especially, the

Table VIII Cumulative excretions of radioactivity in bile, urine and feces after subcutaneous administration of ${ }^{14} \mathrm{C}$-clonidine to male rats (dose: $1 \mathrm{mg} / \mathrm{kg}$ )

\begin{tabular}{crcr}
\hline \multirow{2}{*}{ Time $(\mathrm{hr})$} & \multicolumn{1}{c}{ Excretion of radioactivity (\% of dose) } \\
\cline { 2 - 3 } & \multicolumn{1}{c}{ Bile } & Urine & Feces \\
\hline 1 & $4.3 \pm 0.9$ & - & - \\
2 & $13.5 \pm 2.1$ & - & - \\
4 & $24.5 \pm 2.5$ & $31.9 \pm 1.7$ & - \\
8 & $28.9 \pm 2.7$ & - & $0.1 \pm 0.1$ \\
24 & $30.8 \pm 3.5$ & $59.8 \pm 3.9$ & $0.2 \pm 0.1$ \\
48 & $32.9 \pm 3.3$ & $61.9 \pm 4.1$ & $0.2 \pm 0.0$ \\
Administration site (48 hr) & $33.2 \pm 3.4$ & & $0.0 \pm 0.0$ \\
Gastro-intestinal contents (48 hr) & & & $1.1 \pm 0.2$ \\
Carcass (48 hr) & & &
\end{tabular}

Data are expressed as the mean values \pm S.D. of three animals. 
Table IX Cumulative excretions of radioactivity in bile, urine and feces after intraduodenal injection of bile sample* to male rats (dose: $0.126 \mathrm{mg}$ equiv. of clonidine in bile $/ \mathrm{kg}$ )

\begin{tabular}{cccc}
\hline \multirow{2}{*}{ Time (hr) } & \multicolumn{2}{c}{ Excretion of radioactivity (\% of radioactivity injected) } \\
\cline { 2 - 4 } & Bile & Urine & Feces \\
\hline 1 & $0.1 \pm 0.1$ & - & - \\
2 & $0.6 \pm 0.4$ & $9.5 \pm 3.1$ & - \\
4 & $1.9 \pm 0.8$ & - & - \\
6 & $4.8 \pm 0.5$ & $37.8 \pm 8.0$ & $15.2 \pm 9.8$ \\
8 & $7.1 \pm 2.2$ & $49.2 \pm 5.2$ & $29.2 \pm 3.4$ \\
24 & $10.4 \pm 3.6$ & $51.0 \pm 4.3$ & $4.0 \pm 0.4$
\end{tabular}

Data are expressed as the mean values \pm S.D. of three animals.

- : Not determined.

${ }^{*}$ : Obtained from male rats $(0-8 \mathrm{hr})$ after subcutaneous administration of ${ }^{14} \mathrm{C}$-clonidine (dose: $1 \mathrm{mg} / \mathrm{kg}$ ).

radioactivity concentrations in the mandibular gland, kidney, liver and stomach were 11 to 16 times higher than that in plasma. The radioactivity concentrations in most tissues decreased rapidly to less than $2 \%$ of each maximum at $120 \mathrm{hr}$ after administration. Consequently, it is indicated that the radioactivity administered subcutaneously to rats is rapidly and extensively distributed to the whole body and eliminated rapidly from the body. However, the radioactivities in the aorta and thyroid gland decreased somewhat slowly. The whole body autoradiograms showed reasonable distribution of radioactivity to the above results.

The radioactivity was mainly excreted in the urine with about $70 \%$ of the dose after subcutaneous administration of ${ }^{14} \mathrm{C}$-clonidine to male rats. The radioactivity excreted in the bile was $33 \%$ of the dose and $21 \%$ of the initial dose was re-absorbed but only $4 \%$ of the initial dose was re-excreted in the bile. Therefore, it appears that the role of entero-hepatic circulation in the metabolic fate of clonidine is not important.

To study on the sex difference, female rats were also dosed subcutaneously with $1 \mathrm{mg} / \mathrm{kg}$ of ${ }^{14} \mathrm{C}$-clonidine. Although the ratio of urinary excretion in the female rats was slightly higher than that in the males, the radioactivity concentration in plasma vs. time curve was nearly equal to that in the males. It was estimated that there would be no marked sex difference in the metabolic fate of clonidine.

To study on the species difference, male dogs and a monkey were also dosed subcutaneously with $1 \mathrm{mg} / \mathrm{kg}$ of ${ }^{14} \mathrm{C}$-clonidine. In both species, the radioactivity con- centration in plasma was always higher than that in the rats during the examined period of time. The values of $\mathrm{T}_{\max }$ and half-life of the second phase were larger than those of the rats. The main excretion route in both species was urine similarly to the rats but the ratios were higher than that of the rats.

In conclusion, after subcutaneous administration of ${ }^{14} \mathrm{C}$-clonidine to rats, dogs and a monkey, the following results were obtained on the metabolic fate of clonidine. In male rats, dose linearity was observed in the plasma concentration ranging from 0.25 to $1 \mathrm{mg} / \mathrm{kg}$. The radioactivity was distributed extensively to the whole body with higher concentration than that in the plasma, and was excreted mainly in the urine. Sex difference was estimated to be not so much between the male and female rats. The dogs and a monkey showed a similar pharmacokinetic profile, but the rats showed a different profile from these animals.

\section{References}

1) Timmermans, P. B. M. W. M.: Centrally acting hypotensive drugs. in Van Zwieten, P. A. (ed): Handbook of Hypertension Vol. 3 Pharmacology of Antihypertensive Drugs. Elsevier Science Publishers B. V., Amsterdam; 102-153 (1984).

2) Lowenthal, D. T.: Pharmacokinetics of Clonidine. J. Cardiovasc. Pharmacol., 2 (Suppl. 1): S29-S37 (1980).

3) Rehbinder, D. and Deckers, W.: Untersuchungen zur Pharmakokinetik und zum Metabolismus des 2-(2,6-Dichlorphenylamino)-2-imidazolin-hydrochlorid (St 155). Arzneim.-Forsch./Drug Res., 19: 169-176 (1969). 